\title{
MIKROENKAPSULASI Lactobacillus sp. DENGAN TEKNIK EMULSI DAN APLIKASINYA PADA DODOL SIRSAK
}

\author{
[Microencapsulation of Lactobacillus sp. Using Emulsion Technique \\ and Its Application in Soursop Sweet Cakes]
}

\author{
Anis Usfah Prastu Jati ${ }^{1)}$, Betty Sri Laksmi Jenie ${ }^{2) \star}$, dan Suliantari ${ }^{2)}$ \\ 1) Program Studi Ilmu Pangan, Institut Pertanian Bogor, Bogor \\ 2) Departemen IImu dan Teknologi Pangan, Fakultas Teknologi Pertanian, Institut Pertanian Bogor, Bogor
}

Diterima 25 Februari 2015 / Disetujui 10 Agustus 2015

\begin{abstract}
Two probiotic strains Lactobacillus acidophilus $2 B 4$ and L. rhamnosus $R 23$ were microencapsulated by an emulsion technique using sodium alginate and vegetable oil. The present study aimed to enhance probiotic survival on their application in the production of soursop sweet cakes (dodol sirsak) and their stability during storage at room temperature. The probiotic biomasses were mixed with $3 \%$ sodium alginate and then added dropwise into a mixture of soybean oil and Tween 80 . The microencapsulation technique applied resulted in excellent survival (95-96\%) for both Lactobacillus sp. strains. Encapsulation significantly improved the survival of probiotics $(P<0.05)$ during exposure to heat process $\left(60,65\right.$, and $70^{\circ} \mathrm{C}$ for 20 $\min )$, low $\mathrm{pH}(\mathrm{pH} 2)$ and bile salt (0.5\%). Encapsulation did not alter the ability of both probiotics in inhibiting the growth of Escherichia coli ATCC 25922. The viability of encapsulated strains in soursop sweet cakes were improved to the adequate number, i.e. $6 \mathrm{Log} \mathrm{CFU} \mathrm{g}^{-1}$ up to 3 and 2 weeks storage, as

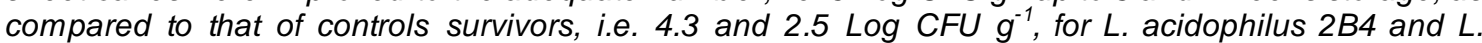
rhamnosus $R 23$, respectively, during a week of storage.
\end{abstract}

Keywords: emulsion technique, Lactobacillus sp., microencapsulation, probiotic, soursop sweet cakes

\begin{abstract}
ABSTRAK
Mikroenkapsulasi dengan teknik emulsi menggunakan natrium alginat dan minyak kedelai dilakukan terhadap dua galur probiotik yaitu Lactobacillus acidophilus 2B4 dan L. rhamnosus R23. Tujuan dari penelitian ini adalah untuk meningkatkan sintasan probiotik pada saat diaplikasikan ke dalam pembuatan dodol sirsak dan stabilitasnya selama penyimpanan pada suhu ruang. Biomassa probiotik dicampurkan ke dalam 3\% natrium alginat dan dimasukkan ke dalam campuran larutan minyak kedelai dan Tween 80. Mikroenkapsulasi dengan teknik emulsi menghasilkan sintasan yang tinggi (95-96\%) pada kedua galur probiotik Lactobacillus sp. Mikroenkapsulasi dapat memperbaiki sintasan probiotik secara signifikan $(P<0,05)$ selama pemaparan panas $\left(60,65\right.$, dan $70^{\circ} \mathrm{C}$, selama 20 menit), $\mathrm{pH}$ rendah $(\mathrm{pH} 2)$ dan garam empedu $(0,5 \%)$. Mikroenkapsulasi tidak menurunkan secara signifikan $(P>0,05)$ kemampuan kedua galur probiotik dalam menghambat pertumbuhan Escherichia coli ATCC 25922. Kedua galur probotik terenkapsulasi yang diaplikasikan dalam dodol sirsak juga lebih stabil selama penyimpanan dodol sirsak dalam jumlah yang diperlukan ( $6 \mathrm{Log} \mathrm{CFU} \mathrm{g}^{-1}$ ) masing-masing selama 3 dan 2 minggu dibandingkan kontrol (dodol sirsak dengan penambahan probiotik bebas) yang hanya bertahan selama kurang dari 1 minggu (4,3 Log CFU g ${ }^{-1}$ untuk L. acidophilus 2B4 dan 2,5 Log CFU g ${ }^{-1}$ untuk L. rhamnosus R23).
\end{abstract}

Kata kunci: dodol sirsak, Lactobacillus sp., teknik emulsi, mikroenkapsulasi, probiotik

\section{PENDAHULUAN}

Probiotik adalah mikroorganisme hidup yang apabila dikonsumsi oleh manusia atau hewan dalam jumlah yang cukup, mampu bertahan hidup ketika melewati kondisi lambung dan saluran pencernaan serta bermanfaat meningkatkan kesehatan inangnya (FAO/WHO, 2002). Dosis yang dibutuhkan untuk mendapatkan efek kesehatan setelah mengonsumsi probiotik tergantung dari galur probiotik yang digunakan.

*Penulis Korespondensi:

E-mail: betty_jenie@yahoo.com 
Secara umum efek kesehatan tersebut akan diperoleh bila mengonsumsi probiotik sekitar 6-7 Log CFU g ${ }^{-1}$ per hari (Krasaekoopt et al., 2003). Oleh karena itu viabilitas probiotik dalam produk perlu diperhatikan. Telah dilaporkan bahwa viabilitas probiotik umumnya mengalami penurunan selama proses pembuatan produk pangan, pada kondisi penyimpanan pangan serta saat dikonsumsi dan melewati sistem saluran pencernaan (Semyonov et al., 2010). Salah satu upaya untuk mempertahankan viabilitas probiotik adalah dengan mengaplikasikan teknik enkapsulasi. Enkapsulasi merupakan suatu teknologi yang telah banyak dikembangkan untuk diaplikasikan dalam industri pangan sebagai upaya perlindungan terhadap sel bakteri (Borgogna et al., 2010). Selain itu enkapsulasi juga bermanfaat dalam menjaga sintasan probiotik selama penyimpanan dan melewati saluran pencernaan. Teknik enkapsulasi yang digunakan pada penelitian ini adalah teknik emulsi, yang dibuat dengan mencampurkan sel bakteri dan natrium alginat di dalam minyak sayur yang kemudian berikatan dengan $\mathrm{CaCl}_{2}$ sehingga menghasilkan kapsul alginat dalam jumlah yang cukup banyak dengan ukuran diameter mikrokapsul antara 20-70 $\mu \mathrm{m}$ (Anal dan Singh, 2007).

Probiotik telah banyak diaplikasikan kedalam berbagai macam produk pangan, seperti pada yogurt (Capela et al., 2006), es krim (Cruz et al., 2009), dan juga coklat hitam (Nebesny et al., 2007). Kebanyakan dari produk pangan yang disuplementasi dengan probiotik adalah produk pangan berbasis susu. Saat ini konsumsi produk probiotik non susu juga cukup meningkat karena adanya tren terkait vegetarian, kandungan kolesterol dalam susu, dan juga gangguan pencernaan seperti intoleransi laktosa (Granato et al., 2010). Penambahan probiotik ke dalam produk pangan berbasis non susu yakni pada pangan jenis Intermediate Moisture Food (IMF) seperti dodol belum pernah dilakukan sebelumnya. Oleh karena itu penelitian ini diharapkan dapat menghasilkan produk dodol yang memiliki nilai tambah manfaat kesehatan sebagai probiotik. Galur probiotik yang digunakan pada penelitian ini terdiri dari Lactobacillus acidophilus 2B4 dan $L$. rhamnosus R23. L. acidophilus 2B4 ini telah dilaporkan dapat mencegah diare yang disebabkan oleh Enterophatogenic Escherichia coli (EPEC) pada tikus percobaan (Arief et al., 2010). Demikian pula $L$. rhamnosus R23 melalui pengujian in vivo juga dilaporkan memiliki kemampuan mencegah diare segera setelah tikus diberi asupan Escherichia coli K1.1 (Nuraida et al., 2012 ${ }^{\mathrm{a}}$ ).

Penelitian ini bertujuan untuk mengetahui pengaruh enkapsulasi dengan teknik emulsi terhadap karakteristik dua galur probiotik (L. Acidophilus 2B4 dan L. rhamnosus R23) meliputi sintasan, ketahanan terhadap panas, keasaman $(\mathrm{pH}$
2), dan kondisi basa (garam empedu 0,5\%) serta aktivitas antimikrobanya terhadap E. coli. Stabilitas probiotik terenkapsulasi yang diaplikasikan dalam dodol sirsak dan mutu mikrobiologi (jumlah kapang dan khamir) dodol sirsak probiotik pada suhu ruang selama penyimpanan juga dievaluasi.

\section{BAHAN DAN METODE}

\section{Bahan}

Kultur probiotik L. acidophilus 2B4 diperoleh dari Fakultas Peternakan IPB, serta L. rhamnosus R23 dan E. coli ATCC 25922 diperoleh dari Laboratorium Mikrobiologi Pangan SEAFAST CENTER IPB. Buah sirsak matang (Pasar Darmaga Bogor) yang digunakan mempunyai derajat kematangan secara fisik sebagai berikut: kulit buah berwarna hijau terang atau hijau kekuningan dan duri di permukaan kulit terlihat jarang (tidak rapat) serta tekstur daging buah empuk (tidak terlalu lembek).

\section{Persiapan kultur probiotik dan produksi bio- massa (Harmayani et al., 2001)}

Sebanyak satu ose probiotik ditumbuhkan pada media MRSB (Oxoid Ltd., Basingstoke, Hampshire, Inggris) kemudian diinkubasi selama 24 jam pada suhu $37^{\circ} \mathrm{C}$. Selanjutnya diambil sebanyak $10 \mathrm{~mL}$ untuk ditumbuhkan kembali dalam $1 \mathrm{~L}$ media MRSB (Oxoid Ltd.) (1:100) yang akan digunakan untuk produksi biomassa. Biomassa dipanen menggunakan alat sentrifugasi (Himac CR 21G, Hitachi, Tokyo, Jepang) $5000 \times g$ selama 20 menit pada $4^{\circ} \mathrm{C}$. Selanjutnya, biomassa dicuci dua kali menggunakan 0,1 M buffer fosfat (Merck, Darmstadt, Jerman) dengan cara disentrifugasi kembali dengan kecepatan $5000 \times g$ selama 20 menit pada $4^{\circ} \mathrm{C}$. Konsentrasi biomassa yang dihasilkan adalah berkisar antara 10 hingga $11 \mathrm{Log} \mathrm{CFU} \mathrm{mL}^{-1}$.

\section{Mikroenkapsulasi probiotik (Mandal et al., 2006)}

Biomassa sel sebanyak $4 \mathrm{~mL}$ dimasukkan ke dalam $20 \mathrm{~mL}$ larutan $3 \%$ natrium alginat (SigmaAldrich Pte. Ltd., Nucleos, Singapura) steril lalu dihomogenkan dengan cara digoyang-goyangkan. Minyak kedelai (Mazola, Mississauga, Ontario, Kanada) sebanyak $100 \mathrm{~mL}$ yang mengandung $0,2 \%$ Tween 80 (pengemulsi), dimasukkan ke dalam gelas piala dan campuran aginat dengan sel bebas ditambahkan dengan cara diteteskan sambil diputar dengan pengaduk magnet. Setelah 5 menit, larutan emulsi yang terbentuk ditambahkan dengan $100 \mathrm{~mL}$ $0,1 \mathrm{M} \mathrm{CaCl}_{2}$ (Merck) secara cepat untuk mengeraskan mikrokapsul dan memecah emulsi. Kapsulkapsul yang telah terbentuk kemudian dipisahkan dari minyak menggunakan alat sentrifugasi (Hermle Z383K, Hermle Labortechnik, Jerman) kecepatan 
$350 \times g$ selama 10 menit pada suhu $4^{\circ} \mathrm{C}$ dan dicuci dua kali dengan akuades. Manik-manik dipisahkan dengan kertas saring, lalu dipindahkan ke dalam cawan petri steril dan disimpan ke dalam refrigerator.

\section{Pengujian sintasan probiotik (Gebara et al., 2013)}

Sintasan probiotik ditentukan dengan menghitung jumlah sel sebelum dan setelah proses mikroenkapsulasi. Mikrokapsul probiotik sebanyak $1 \mathrm{~g}$ didisintegrasikan ke dalam $9 \mathrm{~mL}$ larutan $2 \%$ natrium sitrat (Merck) steril ( $\mathrm{pH} \mathrm{7,0)} \mathrm{kemudian} \mathrm{dihomogeni-}$ sasi dengan menggunakan vorteks selama 5 menit (Krasaekoopt et al., 2004). Selanjutnya probiotik yang sudah keluar dari mikrokapsul lalu dihitung menggunakan metode BAM (2001) dan dinyatakan sebagai rendemen enkapsulasi (RE). RE merupakan jumlah sel bakteri yang dapat bertahan hidup selama proses mikroenkapsulasi dan selama berada di dalam mikrokapsul yang dihitung dengan rumus berikut (Zanjani et al., 2014):

$$
\operatorname{RE}(\%)=\left(\mathrm{N} / \mathrm{N}_{0}\right) \times 100
$$

\section{Keterangan:}

$\mathrm{N}$ : jumlah sel probiotik hidup dalam Log CFU g ${ }^{-1}$ mikrokapsul

$\mathrm{N}_{0}$ : jumlah sel probiotik hidup dalam Log CFU $\mathrm{mL}^{-1}$ kultur

\section{Pengujian ketahanan panas probiotik (Mandal et} al., 2006)

Pengujian ketahanan panas terhadap probiotik bebas dan terenkapsulasi dilakukan dengan menambahkan sampel probiotik bebas sebanyak $1 \mathrm{~mL}$ dan probiotik terenkapsulasi sebanyak $1 \mathrm{~g}$ ke dalam $9 \mathrm{~mL}$ akuades steril dan dihomogenisasi menggunakan vorteks. Selanjutnya larutan tersebut dipanaskan pada suhu 60,65 , dan $70^{\circ} \mathrm{C}$ dengan waterbath selama 20 menit, lalu didinginkan pada suhu ruang. Selanjutnya sintasan probiotik dianalisis berdasarkan prosedur Gebara et al. (2013).

Ketahanan probiotik terhadap $\mathrm{pH}$ rendah (pH 2) dan garam empedu (0,5\%) (Modifikasi Nuraida et al., 2012 ${ }^{\mathrm{b}}$ )

Sebanyak $1 \mathrm{~mL}$ sel probiotik bebas dan $1 \mathrm{~g}$ mikrokapsul masing-masing ditambahkan ke dalam tabung yang berisi $9 \mathrm{~mL}$ MRSB pH 2 dengan menambahkan $0,1 \mathrm{M}$ larutan $\mathrm{HCl}$ (Merck) kemudian dihomogenisasi dengan menggunakan vorteks, untuk pengujian ketahanan terhadap $\mathrm{pH}$ rendah. Selanjutnya tabung-tabung tersebut diinkubasi selama 5 jam pada suhu $37^{\circ} \mathrm{C}$. Perhitungan jumlah koloni probiotik dilakukan pada jam ke-0 dan ke-5 berdasarkan prosedur Gebara et al. (2013). Prosedur yang sama juga dilakukan untuk pengujian ketahanan probiotik terhadap $0,5 \%$ garam empedu (Merck).
Pengujian aktivitas antimikroba probiotik terhadap E. coli ATCC 25922 (Modifikasi Nuraida et al., 2012 ${ }^{\mathrm{a}}$ )

Uji aktivitas antimikroba probiotik dilakukan dengan metode kontak. Sampel sel probiotik terenkapsulasi sebelumnya dikeluarkan terlebih dahulu dari mikrokapsul dengan cara dilarutkan dalam 2\% larutan natrium sitrat (Merck). Sebanyak 0,2 $\mathrm{mL} E$. coli ATCC $25922\left(5,0\right.$ Log CFU mL $\left.{ }^{-1}\right)$ dan $0,2 \mathrm{~mL}$ probiotik bebas $\left(10,0\right.$ Log CFU $\left.\mathrm{mL}^{-1}\right)$ dan terenkapsulasi (10,0 Log CFU $\left.\mathrm{mL}^{-1}\right)$ masing-masing diinokulasikan ke dalam $20 \mathrm{~mL}$ larutan susu skim (Sunlac, Bayan Lepas, Penang, Malaysia) steril dalam erlenmeyer $50 \mathrm{~mL}$, sehingga di dalam susu terkandung 3,0 Log CFU mL $\mathrm{mL}^{-1}$ E. coli ATCC 25922 dan 8,0 Log CFU mL ${ }^{-1}$ probiotik. Selanjutnya seluruh erlenmeyer tersebut dihomogenisasi dengan cara digoyang-goyangkan hingga merata, lalu diinkubasi selama 24 jam pada suhu $37^{\circ} \mathrm{C}$. Jumlah $E$. coli ATCC 25922 dan probiotik dihitung pada waktu kontak 0 dan 24 jam inkubasi dengan metode tuang cawan masing-masing dengan menggunakan media tumbuh EMBA (Oxoid Ltd.) dan MRSA (Oxoid Ltd.).

\section{Pembuatan dodol sirsak probiotik}

Dodol sirsak dibuat sesuai dengan resep produsen dodol (UMKM Dodol Lingkar Kampus IPB Darmaga) yang telah memiliki surat ijin edar dengan No. PIRT 206320101808. Sebanyak 1 butir kelapa bagian daging buah diparut dan diambil santannya kurang lebih $1 \mathrm{~L}$ (terdiri dari $500 \mathrm{~mL}$ santan kental dan $500 \mathrm{~mL}$ santan encer). Gula merah dan gula pasir masing-masing sebanyak $500 \mathrm{~g}$ dilarutkan dengan $500 \mathrm{~mL}$ santan kental kemudian dipanaskan hingga larut kemudian disaring dengan saringan plastik. Sebanyak $500 \mathrm{~g}$ tepung ketan dilarutkan dengan $500 \mathrm{~mL}$ santan encer di dalam wajan hingga tidak ada yang menggumpal, kemudian ditambahkan larutan gula. Selanjutnya sebanyak $500 \mathrm{~g}$ daging buah sirsak ditambahkan ke dalam adonan tepung ketan dan dimasak di atas kompor sambil diaduk selama lebih kurang 120 menit atau sampai adonan kalis dengan penampakan yang mengkilat atau tampak berminyak, tidak lengket dan berwarna coklat. Adonan dodol sirsak yang sudah matang kemudian dibiarkan sampai suhunya $60^{\circ} \mathrm{C}$. Selanjutnya dodol sirsak yang telah matang (suhu $60^{\circ} \mathrm{C}$ ) ditimbang sebanyak $15 \mathrm{~g}$ lalu ke dalamnya ditambahkan dengan probiotik terenkapsulasi sebanyak 1 g yang berisi sekitar 9-10 Log CFU g ${ }^{-1}$, kemudian plastik yang berisi dodol sirsak probiotik tersebut diikat. Sebagai kontrol, dodol sirsak berisi probiotik bebas sebanyak $1 \mathrm{~mL}$ dipersiapkan dengan cara yang sama. Selanjutnya dodol sirsak disimpan pada suhu kamar (lebih kurang $30^{\circ} \mathrm{C}$ ) dan diuji viabilitas probiotik serta jumlah kapang dan khamir setiap minggu hingga penyimpanan 4 minggu. 
Pengukuran viabilitas probiotik dan total kapang dan khamir selama penyimpanan dodol sirsak probiotik (Modifikasi BAM, 2001)

Sebanyak $15 \mathrm{~g}$ sampel dodol sirsak probiotik dihancurkan menggunakan alat penghancur kemudian dilarutkan dengan $135 \mathrm{~mL}$ larutan pengencer $0,85 \%$ (b/v) $\mathrm{NaCl}$ (Oxoid Ltd.) untuk dodol sirsak dengan penambahan probiotik bebas, dan $135 \mathrm{~mL}$ larutan pengencer $2 \%$ natrium sitrat (Merck) untuk dodol sirsak dengan penambahan probiotik terenkapsulasi. Sebanyak $1 \mathrm{~mL}$ dari masing-masing larutan tersebut diinokulasikan ke dalam cawan lalu ditambahkan media MRSA (Oxoid Ltd.) untuk probiotik dan cawan diinkubasi selama 48 jam pada suhu $37^{\circ} \mathrm{C}$. Untuk perhitungan total kapang dan khamir, sebanyak $1 \mathrm{~mL}$ yang mengandung sel probiotik tersebut ditumbuhkan pada media PDA (Oxoid Ltd.) yang ditambah dengan larutan asam tartarat (Merck) sebanyak $14 \mathrm{~mL} \mathrm{~L}^{-1}$ dan diinkubasi selama 5 hari pada suhu ruang (lebih kurang $30^{\circ} \mathrm{C}$ ).

\section{Analisis data}

Data sintasan probiotik bebas dan terenkapsulasi dari hasil pengujian ketahanan terhadap panas, $\mathrm{pH}$ rendah, garam empedu, antimikroba serta selama penyimpanan yang merupakan nilai rata-rata dari dua kali ulangan dan dianalisis menggunakan analisis ragam atau Analysis of variance (ANOVA) dengan software SPSS 15. Apabila hasil ANOVA menunjukkan adanya perbedaan pada perlakuan maka dilanjutkan dengan uji beda nyata Duncan dengan taraf nyata $5 \%$.

\section{HASIL DAN PEMBAHASAN}

\section{Rendemen sel probiotik setelah enkapsulasi}

Probiotik yang dienkapsulasi dengan teknik emulsi menggunakan natrium alginat sebanyak $3 \%$ menghasilkan rendemen yang tinggi baik untuk $L$. acidophilus 2B4 maupun L. rhamnosus R23 yaitu sebesar 95,4-95,6\%. Rendemen enkapsulasi (RE) dihitung berdasarkan jumlah sel probiotik yang hidup setelah proses mikroenkapsulasi dibagi dengan jumlah sel bebas yang ditambahkan pada campuran biopolimer selama proses mikroenkapsulasi. Berdasarkan hasil analisis statistik, viabilitas probiotik sebelum dan setelah proses mikroenkapsulasi tidak berpengaruh secara nyata $(P>0,05)$ terhadap jumlah sel probiotik.

Hal tersebut menunjukkan bahwa mikroenkapsulasi tidak menyebabkan penurunan jumlah sel probiotik secara signifikan terhadap sel probiotik karena mikroenkapsulasi dengan teknik emulsi ini tidak menggunakan bahan-bahan perlakuan yang dapat mempengaruhi sintasan sel probiotik. Mikroenkapsulasi merupakan suatu proses dimana sel probiotik dilindungi dengan cara penyalutan membran untuk mengurangi sel yang hilang. Selain itu, mikroenkapsulasi dengan teknik emulsi juga dapat meningkatkan sintasan probiotik hingga sebesar $80-95 \%$ (Krasaekoopt et al., 2003). Enkapsulasi $L$. casei menggunakan natrium alginat dengan teknik ekstrusi yang dilakukan oleh Sandoval et al. (2010) menghasilkan angka efisiensi enkapsulasi yang bervariasi yaitu antara $54,3-79,2 \%$. Zanjani et al. (2014) juga melaporkan bahwa mikroenkapsulasi dengan teknik emulsi pada galur probiotik $L$. casei dan Bifidobacterium bifidum yang dienkapsulasi dengan natrium alginat menggunakan teknik emulsi adalah sebesar $97,4 \%$.

\section{Sintasan probiotik selama pemaparan dengan panas}

Perlakuan pemanasan $\left(60,65\right.$, dan $\left.70^{\circ} \mathrm{C}\right)$ selama 20 menit memberikan pengaruh yang berbeda terhadap sintasan probiotik bebas dan terenkapsulasi. Gambar 1 menunjukkan bahwa pemaparan panas dengan suhu $60^{\circ} \mathrm{C}$ menyebabkan penurunan jumlah sel yang cukup besar pada probiotik bebas baik pada $L$. acidophilus 2B4 maupun pada $L$. rhamnosus R23 yaitu sebesar 4,0 dan 3,9 Log CFU $g^{-1}$. Demikian pula pada pemaparan suhu 65 dan $70^{\circ} \mathrm{C}$ yang juga menyebabkan penurunan yang besar terhadap probiotik bebas. Hal tersebut menunjukkan bahwa semakin tinggi suhu pemaparan panas terhadap probiotik bebas menyebabkan penurunan sintasan yang semakin besar. Dapat dilihat pada Gambar 1 bahwa sintasan probiotik terenkapsulasi yang mendapat paparan panas dengan tiga suhu tersebut mengalami penurunan sintasan yang lebih kecil. Hal tersebut menunjukkan bahwa mikroenkapsulasi dengan teknik emulsi dapat melindungi probiotik dari paparan panas baik pada $L$. acidophilus 2B4 maupun L. rhamnosus R23 terutama pada suhu $60^{\circ} \mathrm{C}$ dengan penurunan sintasan yang paling kecil, yaitu sebesar 2,7 Log CFU g ${ }^{-1}$ pada $L$. acidophilus 2B4 dan 3,2 Log CFU g ${ }^{-1}$ pada L. rhamnosus R23.

Hasil analisis statistik menunjukkan bahwa proses mikroenkapsulasi menggunakan alginat berpengaruh nyata $(P<0,05)$ terhadap sel probiotik, yakni probiotik terenkapsulasi untuk kedua galur lebih tahan terhadap pemanasan dibandingkan dengan sel bebas. Menurut Krasaekoopt et al. (2003) proses mikroenkapsulasi dengan manik hidrogel seperti alginat, dapat memerangkap probiotik dan membuatnya imobil di dalam matriks gelnya, serta memberikan perlindungan pada sel probiotik terhadap kondisi lingkungannya, seperti kondisi pemanasan. Hasil serupa dilaporkan oleh Kim et al. (2008), galur probiotik L. acidophilus ATCC 43121 yang dienkapsulasi dengan natrium alginat menggunakan teknik ekstrusi dapat meningkatkan ketahanan panas bakteri tersebut. 


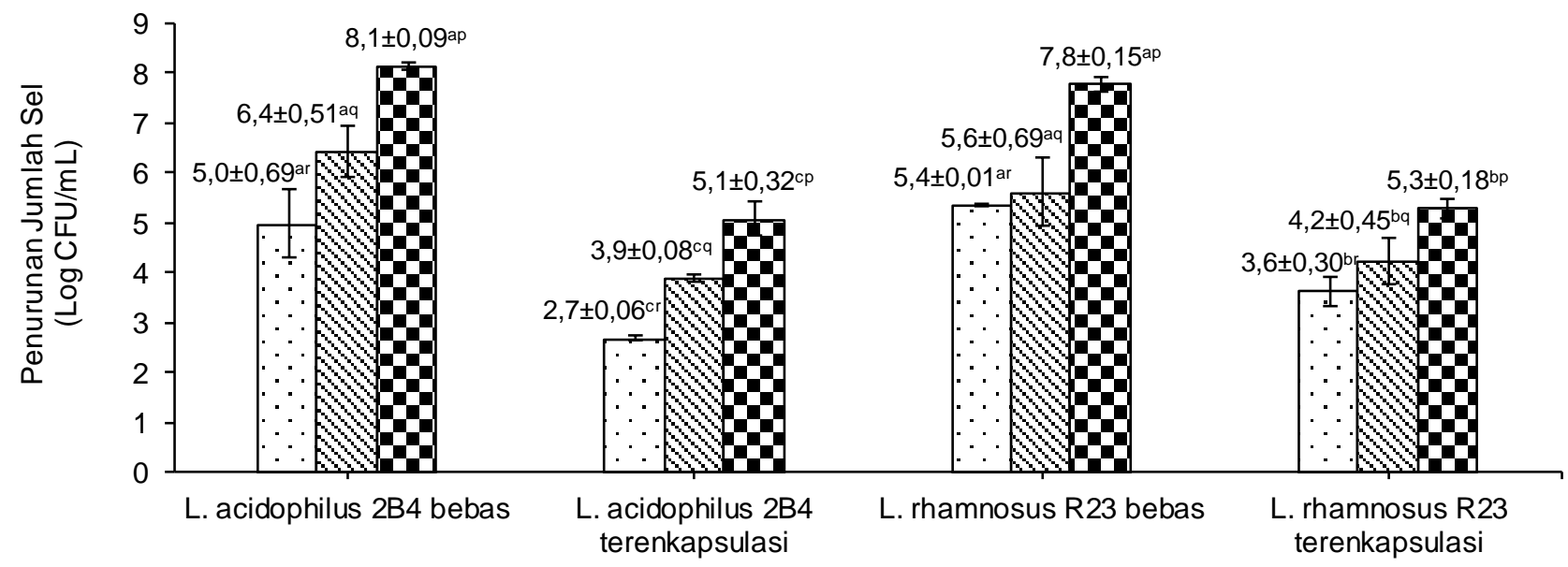

$\square 60 \circ \mathrm{OC} \quad \square 65 \circ \mathrm{OC} \quad \square 70$ oC

Strain Probiotik

Gambar 1. Sintasan probiotik selama pemaparan panas L. acidophilus 2B4 dan L. rhamnosus R23 bebas dan terenkapsulasi. Batang histogram yang sama yang diikuti oleh huruf yang berbeda (a-c) berbeda nyata $(P<0,05)$ pada galur yang sama dan suhu yang berbeda. Batang histogram yang sama yang diikuti oleh huruf yang berbeda $(p-r)$ berbeda nyata $(P<0,05)$ pada suhu yang sama dan galur yang berbeda

\section{Ketahanan probiotik terhadap $\mathrm{pH}$ rendah dan garam empedu}

Mikroenkapsulasi probiotik juga meningkatkan ketahanan baik terhadap $\mathrm{pH}$ rendah $(\mathrm{pH} 2)$ maupun garam empedu $0,5 \%$ secara nyata (Gambar 2). Sintasan L. acidophilus 2B4 dan $L$. rhamnosus $\mathrm{R} 23$ bebas pada $\mathrm{pH} 2$ mengalami penurunan cukup besar yaitu sebesar 4,4 dan 5,3 Log CFU $\mathrm{mL}^{-1}$. Gambar $2 \mathrm{~A}$ menunjukkan bahwa mikroenkapsulasi terbukti mampu melindungi probiotik dari kondisi $\mathrm{pH} 2$ selama 5 jam yaitu dengan penurunan jumlah sel probiotik yang lebih kecil baik pada L. acidophilus 2B4 maupun L. rhamnosus R23 dimana masing-masing mengalami penurunan sebesar 2,4 dan 1,6 Log CFU g ${ }^{-1}$. Hal tersebut serupa dengan hasil penelitian Ding dan Shah (2008), bahwa jumlah sel L. acidophilus dan L. rhamnosus terenkapsulasi dengan natrium alginat yang hidup setelah dilakukan pengujian pada $\mathrm{pH}$ 2,81 adalah sekitar 5,2 Log CFU $\mathrm{mL}^{-1}$. Hasil analisis statistik menunjukkan bahwa perlakuan mikroenkapsulasi berpengaruh nyata $(P<0,05)$ terhadap sintasan probiotik pada kondisi $\mathrm{pH} 2$. Hal tersebut dikarenakan jaringan hidrogel (alginat) yang dibentuk oleh bahan enkapsulan dapat mereduksi kecepatan difusi asam ke dalam mikrokapsul (Shi et al., 2013).

Gambar 2B menunjukkan bahwa mikroenkapsulasi juga mampu melindungi probiotik dalam kondisi garam empedu $0,5 \%$ selama 5 jam, yaitu pada kondisi tersebut $L$. acidophilus 2B4 dan $L$. rhamnosus R23 terenkapsulasi mengalami penurunan sintasan yang lebih kecil dari sel bebas, masing-masing sebesar 3,4 dan 2,1 Log CFU g ${ }^{-1}$. Hasil analisis statistik menunjukkan bahwa probiotik terenkapsulasi memiliki ketahanan yang lebih baik $(P<0,05)$ terhadap garam empedu $0,5 \%$ selama 5 jam dibandingkan dengan probiotik bebas. Mandal et al. (2006) yang menggunakan konsentrasi garam empedu lebih tinggi dari penelitian ini yaitu sebanyak $1 \%$ selama 12 jam juga mengungkapkan bahwa mikroenkapsulasi menggunakan alginat dengan teknik emulsi dapat memperbaiki viabilitas sel dibandingkan sel bebas (jumlah sel bebas turun dari 9,45 menjadi 7,29 Log CFU mL ${ }^{-1}$ ).

Kim et al. (2008) melaporkan hal serupa, bahwa mikroenkapsulasi dengan teknik pengeringan beku menggunakan natrium alginat dapat meningkatkan sintasan L. acidophilus ATCC 43121 pada konsentrasi garam empedu $0,5 \%$ selama 24 jam. Sel probiotik bebas pada kondisi tersebut sintasannya menurun menjadi 6 Log CFU mL ${ }^{-1}$ sedangkan sel yang dienkapsulasi tidak mengalami penurunan dari jumlah sel awal yaitu sekitar 6,9 Log CFU mL-1. Mokarram et al. (2009) juga melaporkan bahwa formasi hidrogel yang menyelimuti sel probiotik diduga menjadi basis perlindungan sel, dimana larutan asam dan garam empedu perlu menembus melewati lapisan gel tersebut terlebih dahulu sebelum mencapai sel probiotik.

\section{Aktivitas antimikroba probiotik terhadap E. coli ATCC 25922}

Hasil pengujian aktivitas antimikroba probiotik bebas dan terenkapsulasi terhadap $E$. coli ATCC 25922 menunjukkan bahwa mikroenkapsulasi tidak mempengaruhi kemampuan antimikroba terhadap $E$. coli ATCC 25922 secara nyata $(P>0,05)$, dimana sel probiotik bebas maupun terenkapsulasi dapat meng- 
hambat pertumbuhan bakteri uji sebesar 0,9 hingga 1 Log CFU mL $\mathrm{m}^{-1}$. Hasil tersebut menunjukkan penurunan jumlah sel $E$. coli ATCC 25922 dari jumlah awal 4,3 menjadi 3,3 hingga 3,0 Log CFU $\mathrm{mL}^{-1}$. Golowczyc et al. (2011) juga melaporkan bahwa mikroenkapsulasi Lactobacillus plantarum 83114 dan L. kefir 8321 yang dienkapsulasi dengan teknik pengeringan semprot tetap mempertahankan kemampuannya untuk menempel pada sel usus. $L$. kefir 8321 juga tetap dapat melindungi sel usus terhadap invasi Salmonella.
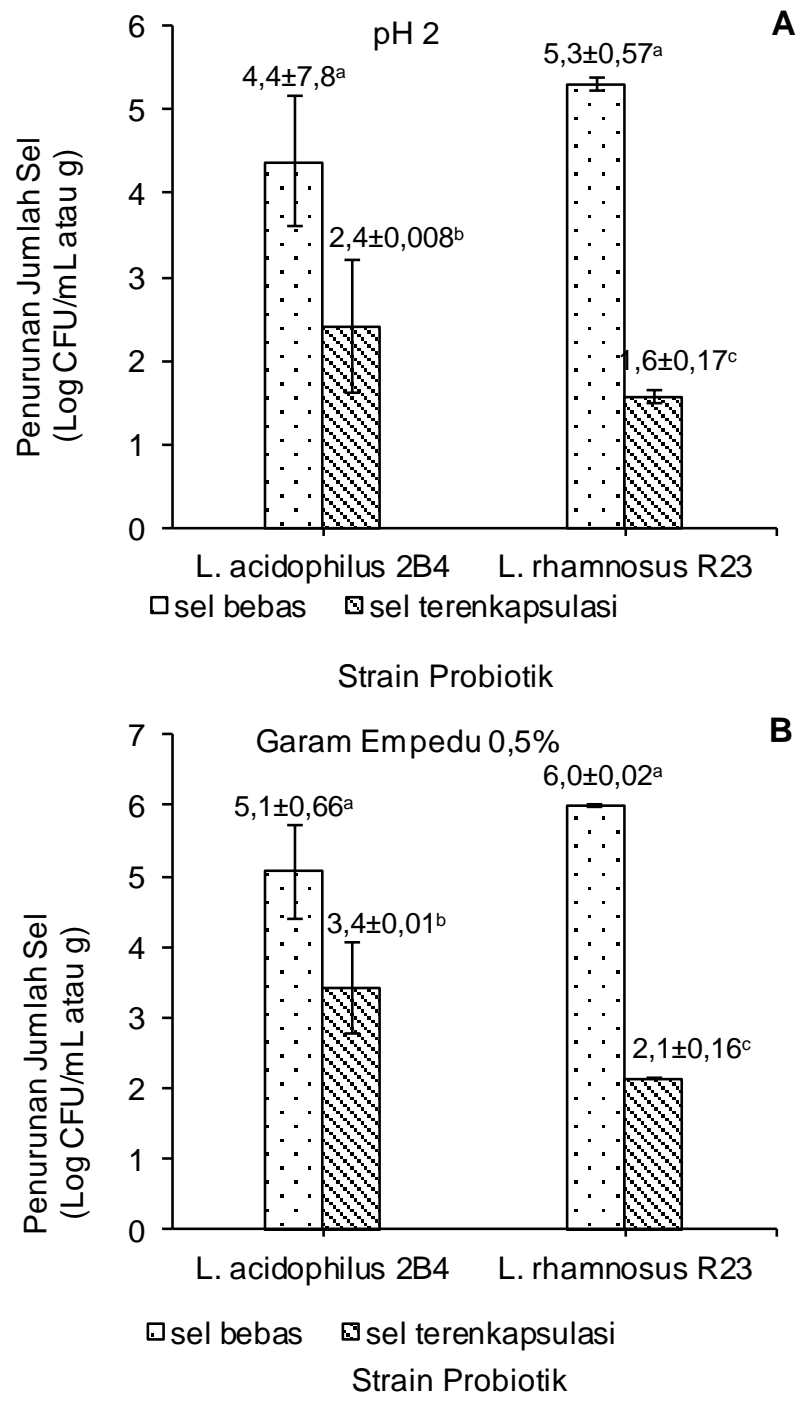

Gambar 2. Sintasan probiotik selama berada pada kondisi: (A) $\mathrm{pH} 2$ dan (B) garam empedu $0,5 \%$. Batang histogram yang sama yang diikuti oleh huruf yang berbeda (ac) berbeda nyata pada $(P<0,05)$

\section{Viabilitas probiotik pada dodol sirsak selama penyimpanan}

Kedua jenis galur probiotik baik bebas maupun terenkapsulasi yang ditambahkan ke dalam dodol sirsak selanjutnya disimpan pada suhu ruang. Viabilitas probiotik diamati setiap 1 minggu. Jumlah sel probiotik bebas dan terenkapsulasi yang berada di dalam dodol sirsak (Gambar 3) mengalami penurunan secara nyata $(P<0,05)$. Probiotik bebas yang ditambahkan segera ke dalam adonan dodol sirsak $\left(60^{\circ} \mathrm{C}\right)$ yaitu sebanyak $9,1 \mathrm{Log}^{\mathrm{CFU}} \mathrm{g}^{-1} \mathrm{~L}$. acidophilus 2B4 dan 10,6 Log CFU g ${ }^{-1}$ L. rhamnosus R23. Setelah dimasukkan ke dalam dodol sirsak, probiotik bebas mengalami penurunan cukup besar yaitu sekitar 3,5 dan 4,5 Log CFU g ${ }^{-1}$ pada kedua galur tersebut. Hal tersebut dapat terjadi dikarenakan inkorporasi probiotik bebas ke dalam dodol sirsak dilakukan pada saat dodol sirsak bersuhu $60^{\circ} \mathrm{C}$ dimana sesuai dengan hasil pengujian ketahanan panas probiotik bebas yang dipanaskan pada suhu $60^{\circ} \mathrm{C}$ jumlah sel yang hidup menurun sebanyak 5,0 dan 5,4 Log CFU g ${ }^{-1}$ masing-masing pada $L$. acidophilus 2B4 dan L. rhamnosus R23.

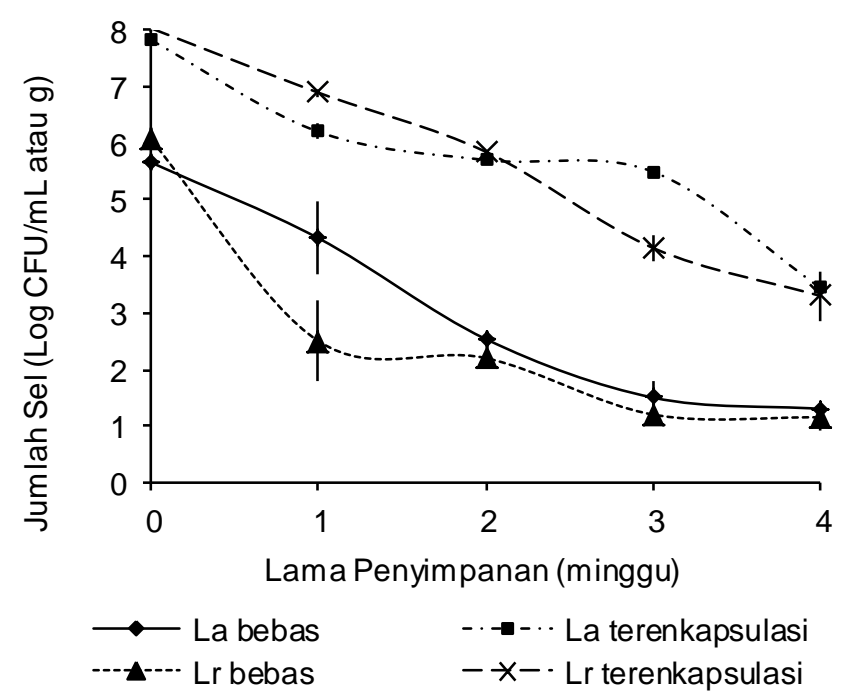

Gambar 3. Viabilitas probiotik di dalam dodol sirsak selama penyimpanan pada suhu ruang. (La: L. acidophilus 2B4; Lr: $L$. rhamnosus R23)

Penurunan jumlah sel probiotik bebas yang cukup besar pada minggu pertama penyimpanan diduga karena sel bebas tidak mampu bertahan hidup di dalam kondisi lingkungan dodol sirsak yang memiliki karakteristik seperti kadar gula tinggi $(51,6 \%)$, kadar air rendah $(18,6 \%)$ dan $a_{w}$ yang rendah yakni sekitar 0,81 . Probiotik bebas mampu bertahan hidup pada kondisi lingkungan yang mengandung gula sederhana dengan kadar air tinggi dan juga nilai $a_{w}$ diatas 0,9 . Nilai $\mathrm{pH}$ dodol sirsak probiotik cenderung stabil pada kisaran angka 4,44,6 sehingga dapat dipastikan bahwa kondisi tersebut tidak mengganggu probiotik selama berada dalam dodol sirsak karena probiotik mampu hidup pada kisaran $\mathrm{pH}$ tersebut. 


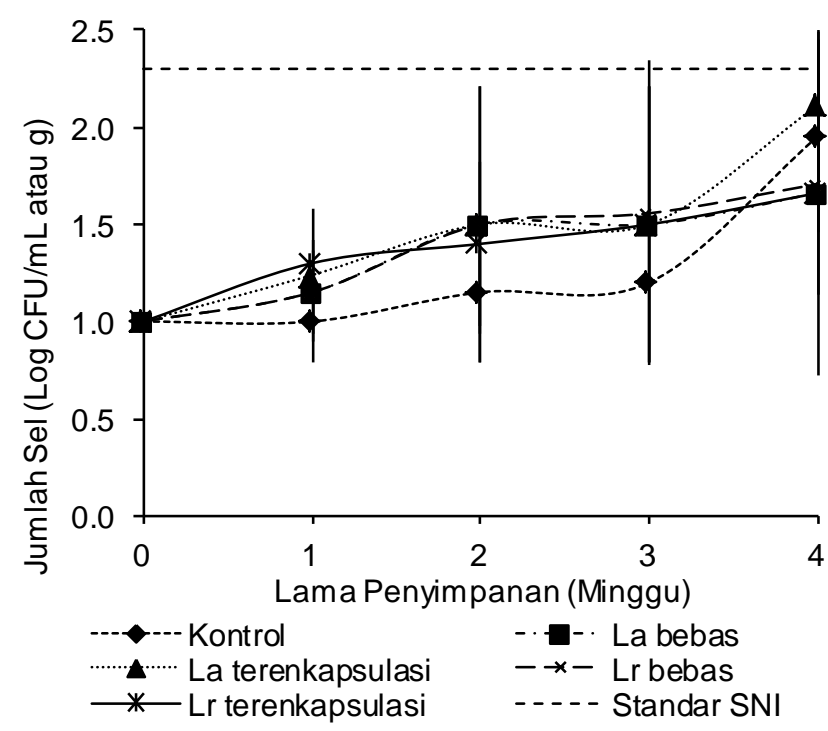

Gambar 4. Jumlah kapang dan khamir produk dodol sirsak probiotik selama penyimpanan pada suhu ruang. (La: $L$. acidophilus 2B4; Lr: L. rhamnosus R23)

Gambar 3 juga memperlihatkan bahwa viabilitas probiotik terenkapsulasi selama berada dalam dodol sirsak mengalami penurunan yang lebih kecil dibandingkan dengan probiotik bebas, yaitu sebesar 1,4 Log CFU $g^{-1}$ pada L. acidophilus 2B4 dan 2,2 Log CFU g ${ }^{-1}$ pada $L$. rhamnosus R23 sehingga jumlah sel probiotik yang hidup dalam dodol sirsak menjadi 7,9 dan 8 Log CFU g ${ }^{-1}$. Hal tersebut menunjukkan bahwa mikroenkapsulasi dapat melindungi sel probiotik selama berada dalam kondisi ekstrim seperti pada dodol sirsak sehingga selama penyimpanan jumlah sel probiotik terenkapsulasi cenderung lebih stabil dibandingkan dengan probiotik bebas. Untuk itu dari Gambar 3 juga dapat dilihat bahwa dodol sirsak probiotik dapat dikonsumsi dengan jumlah yang dibutuhkan (sekitar 6 Log CFU g ${ }^{-1}$ ) hingga umur 3 minggu untuk galur $L$. acidophilus 2B4 dan 2 minggu untuk galur $L$. rhamnosus R23. Dengan demikian telah memenuhi persyaratan dimana untuk mendapatkan manfaat kesehatan probiotik yaitu dengan jumlah sel yang hidup minimal 6-7 Log CFU g ${ }^{-1}$ per hari (Krasaekoopt et al. (2003).

Selama penyimpanan dilakukan juga perhitungan kapang dan khamir yang dapat tumbuh dan merusak pangan dengan kadar gula tinggi dan $a_{w}$ rendah seperti dodol sirsak. Gambar 4 menunjukkan kapang dan khamir telah tumbuh sejak minggu pertama penyimpanan, bahkan meningkat dari 1 hingga 2,1 Log CFU g ${ }^{-1}$ hingga akhir penyimpanan (minggu ke-4). Hal tersebut disebabkan oleh karakteristik kapang dan khamir yang umumnya dapat tumbuh dengan baik di dalam produk pangan dengan kadar gula tinggi dengan kisaran $a_{w}$ 0,85 atau kurang, juga mampu bertahan hidup pada kondisi $\mathrm{pH} 2$ hingga diatas 9 dan dapat hidup pada kisaran suhu $10-35^{\circ} \mathrm{C}$ (BSN, 2009).

Pertumbuhan kapang dan khamir tersebut juga dapat menunjukkan umur simpan dodol sirsak probiotik itu sendiri. Gambar 4 menunjukkan bahwa umur simpan dodol sirsak probiotik hanya dapat bertahan hingga 3 minggu dengan total kapang dan khamir sekitar 2 Log CFU g ${ }^{-1}$. Batasan cemaran mikroba pada dodol menurut BSN (2009) dan BPOM (2009) untuk kapang dan khamir adalah maksimal 2,3 Log CFU g ${ }^{-1}$. Jumlah kapang dan khamir yang terhitung dalam dodol sirsak probiotik tersebut masih dibawah batas aman cemaran kapang dan khamir pada dodol, sehingga produk tersebut masih aman untuk dikonsumsi. Kerusakan pada dodol tidak hanya dapat disebabkan karena adanya kapang dan khamir namun dodol juga dapat mengalami kerusakan seperti ketengikan akibat proses oksidasi senyawa aldehid dan peroksida yang berasal dari santan (Triwarsita et al., 2013).

\section{KESIMPULAN}

Mikroenkapsulasi dengan teknik emulsi dapat meningkatkan sintasan probiotik baik terhadap suhu pemanasan $\left(60,65\right.$, dan $\left.70^{\circ} \mathrm{C}\right)$, $\mathrm{pH} 2$ serta garam empedu $(0,5 \%)$. Mikroenkapsulasi juga dapat meningkatkan stabilitas probiotik yang ditambahkan ke dalam dodol sirsak selama penyimpanan pada suhu ruang. Mikroenkapsulasi pada kedua galur probiotik menunjukkan hasil terbaik untuk galur $L$. acidophilus 2B4 yakni pada perlakuan pemanasan, sedangkan untuk $L$. rhamnosus R23 pada perlakuan $\mathrm{pH} 2$, garam empedu $0,5 \%$ serta aktivitas antimikroba. Probiotik terenkapsulasi dalam produk dodol sirsak jumlahnya lebih stabil dari sel bebas. Jumlah probiotik yang dienkapsulasi dapat dipertahankan pada jumlah yang diperlukan (6 Log CFU g ${ }^{-1}$ ) selama 3 minggu untuk galur $L$. acidophilus 2B4 dan 2 minggu untuk galur $L$. rhamnosus R23, sedangkan probiotik bebas hanya mampu bertahan kurang dari 1 minggu.

\section{UCAPAN TERIMA KASIH}

Ucapan terima kasih ditunjukkan kepada Direktorat Pendidikan Tinggi Kemendikbud atas didanainya penelitian ini melalui program Hibah Kompetensi tahun anggaran 2014 dan juga kepada Bapak Anjay Bustomi (Produsen Dodol Lingkar Kampus Binaan LPPM IPB) yang telah bersedia memberikan informasi mengenai pembuatan dodol sirsak. 


\section{DAFTAR PUSTAKA}

Anal AK, Singh H. 2007. Recent advances in microencapsulation of probiotics for industrial applications and targeted delivery. Trends Food Sci Tech 18: 240-251. DOI: 10.1016/j.tifs.2007. 01.004.

Arief II, Jenie BSL, Astawan M, Witarto AB. 2010. Efektivitas probiotik Lactobacillus plantarum 2C12 dan Lactobacillus acidophilus 2B4 sebagai pencegah diare pada tikus percobaan. Media Peternakan 33: 137-143. DOI: 10.5398/ medpet.2010.33.3.137.

[BAM] Bacteriological Analytical Manual. 2001. Chapter 3: Aerobic plate count. U.S. food and drug administration. www.fda.gov/Food/ Scien ceResearch/LaboratoryMethods/Bacteriological AnalyticalManualBAM/ucm063346.html. [18 Maret 2014]

[BPOM] Badan Pengawas Obat dan Makanan. 2009. Jenis dan Batas Maksimum Cemaran Mikroba Dalam Makanan. Jakarta (ID): BPOM.

[BSN] Badan Standardisasi Nasional. 2009. Batas Maksimum Cemaran Mikroba Dalam Makanan. Jakarta (ID): SNI 7388:2009.

Borgogna $M$, Bellich $B$, Zorzin L, Lapasin R, Cesàro A. 2010. Food microencapsulation of bioactive compounds: rheological and thermal characterisation of non-conventional gelling system. Food Chem 122: 416-423. DOI: 10.1016/j.food chem.2009.07.043.

Capela P, Hay TKC, Shah NP. 2006. Effect of cryoprotectants, prebiotics and microencapsulation on survival of probiotic organisms in yoghurt and freeze-dried yoghurt. Food Res Int 39: 203-211. DOI: 10.1016/j.foodres.2005.07. 007.

Cruz AG, Antunes AEC, Sousa ALOP, Faria JAF, Saad SMI. 2009. Ice-cream as a probiotic food carrier. Food Res Int 42: 1233-1239. DOI: 10. 1016/j.foodres.2009.03.020.

Ding WK, Shah NP. 2008. Survival of free and microencapsulated probiotic bacteria in orange and apple juices. Int Food Res J 15: 219-232.

[FAO/WHO] Food and Agriculture Organization/ World Health Organization of the United Nations. 2002. Evaluation of Health and Nutritional Properties of Probiotics in Food including Powder Milk with Live Lactic Acid Bacteria. C'ordoba.

Gebara C, Chaves KS, Ribeiro MCE, Souza FN, Grosso CRF, Gigante ML. 2013. Viability of Lactobacillus acidophilus La5 in pectin-whey protein microparticles during exposure to simulated gastrointestinal conditions. Food Res Int 51: 872-878. DOI: 10.1016/j.foodres.2013. 02.008

Golowczyc MA, Silva J, Abraham AG, De Antoni GL, Teixeira P. 2011. Cellular injuries of spray dried Lactobacillus spp. isolated from kefir and their impact on probiotic properties. Int $\mathrm{J}$ Food Microbiol 144: 556-560. DOI: 10.1016/j.ijfood micro.2010.11.005.

Granato D, Branco GF, Nazzaro F, Cruz AG, Faria JAF. 2010. Functional foods and nondairy probiotic food development: trends, concepts, and products. Compr Rev Food Sci Food F 9: 292-302. DOI: 10.1111/j.1541-4337.2010.001 10.x.

Harmayani E, Ngatirah, Rahayu ES, Utami T. 2001. Ketahanan dan viabilitas probiotik bakteri asam laktat selama proses pembuatan kultur kering dengan metode freeze dan pengeringan semprot. J Teknol Industri Pangan 12: 126-132.

Kim SJ, Cho SY, Kim SH, Song OJ, Shin IS, Cha DS, Park HJ. 2008. Effect of microencapsulation on viability and other characteristics in L. acidophilus ATCC 43121. LWT-Food Sci Technol 41: 493-500. DOI: 10.1016/j.Iwt.2007. 03.025 .

Krasaekoopt W, Bhandari B, Deeth H. 2003. Evaluation of encapsulation techniques of probiotics for yoghurt. Int Dairy J 13: 3-13. DOI: 10.1016/S0958-6946(02)00155-3.

Krasaekoopt W, Bhandari B, Deeth H. 2004. The influence of coating materials on some properties of alginate beads and survivability of microencapsulated probiotic bacteria. Int Dairy J 14: 737-743. DOI: 10.1016/j.idairyj.2004.01. 004.

Mandal S, Puniya AK, Singh K. 2006. Effect of alginate concentration on survival of microencapsulated Lactobacillus casei NCDC 298. Int Dairy J 16: 1190-1195. DOI: 10.1016/j.idairyj. 2005.10.005.

Mokarram RR, Mortazavi SA, Najafi MBH, Shahidi F. 2009. The influence of multi stage alginate coating on survivability of potential probiotic bacteria in simulated gastric and intestinal juice. Food Res 42: 1040-1045. DOI: 10.1016/j.food res.2009.04.023.

Nebesny E, Zyzelewicz D, Motyl I, Libudzisz Z. 2007. Dark chocolates supplemented with Lactobacillus strains. Eur Food Res Technol 255: 33-42. DOI: 10.1007/s00217-006-0379-9. 
Nuraida L, Hana, Hartanti AW, Prangdimurti E. $2012^{a}$. Potensi Lactobacillus yang diisolasi dari air susu ibu untuk mencegah diare. J Teknol Industri Pangan 22: 158-164. DOI: 10.6066/jtip. 2012.23.2.158.

Nuraida L, Susanti, Palupi NS, Hana, Bastomi RR, Priscillia D, Nurjanah S. $2012^{\mathrm{b}}$. Evaluation of probiotics properties of lactic acid bacteria isolated from breast milk and their potency as starter culture for yoghurt fermentation. Int $\mathrm{J}$ Food Nut Public Health 5: 33-60.

Sandoval OC, Labato CC, Garcia HSG, Alvarez JR, Vernon EJC. 2010. Textural properties of alginate-pectin beads and survivability of entrapped $L b$. casei in simulated gastrointestinal conditions and in yoghurt. Food Res Int 43: 111-117. DOI: 10.1016/j.foodres.2009.09.010.

Semyonov D, Ramon O, Kaplun Z, Levin-Brener L, Gurevich N, Shimoni E. 2010. Microencapsulation of Lactobacillus paracasei by spray freeze drying. Food Res Int 43: 193-202. DOI: 10.1016/j.foodres.2009.09.028.

Shi LE, Li ZH, Li DT, Xu M, Chen HY, Zhang ZL, Tang ZX. 2013. Encapsulation of probiotic Lactobacillus bulgaricus in alginate-milk microspheres and evaluation of the survival in simulated gastrointestinal conditions. J Food Eng 117: 99-104. DOI: 10.1016/j.jfoodeng. 2013.02.012.

Triwarsita WSA, Atmaka W, Muhammad DRA. 2013. Pengaruh penggunaan edible coating pati sukun (Artocarpus altilis) dengan variasi konsentrasi gliserol sebagai plasticizer terhadap kualitas jenang dodol selama penyimpanan. J Teknosains Pangan 2: 124-132.

Zanjani MAK, Tarzi BG, Sharifan A, Mohammadi N. 2014. Microencapsulation of probiotics by calcium alginate-gelatinized starch with chitosan coating and evaluation of survival in simulated human gastrointestinal condition. Iran J Pharm Res 13: 843-852. 